Copyright (C) 2015 by Academic Publishing House Researcher

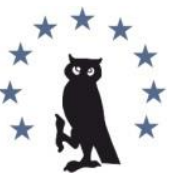

Published in the Russian Federation

European Researcher

Has been issued since 2010.

ISSN 2219-8229

E-ISSN 2224-0136

Vol. 101, Is. 12, pp. 783-790, 2015

DOI: 10.13187/er.2015.101.783

www.erjournal.ru



UDC 37

\title{
Perceptions of Students towards Quality of Services at Private Higher Education Institution in Bosnia and Herzegovina
}

\author{
${ }^{1}$ Aldina Rastoder \\ 2 Ekrem Nurović \\ 3 Edin Smajić \\ 4 Ensar Mekić
}

International Burch University, Bosnia and Herzegovina

aldinarastoder@yahoo.com

ekrem.nurovic@gmail.com

edin.smajic@ibu.edu.ba

ensar.mekic@ibu.edu.ba

\section{Abstract}

The main objective of this exploratory study is to provide insights into perceptions of students towards quality of services at private higher education institution Star, located in B\&H. A survey as a main instrument has been developed, and 448 students participated in the study. Main methodology used for purpose of data analysis is descriptive statistics. Findings indicated that students are either "slightly satisfied" or "satisfied" when it comes to nine aspects of quality at higher education Star. The highest satisfaction level appeared when it comes to "Quality of Academic Staff" which means that this is definitely one of important strengths of the institution. Even though students are still satisfied with "Quality of Campus", the satisfaction level appeared to be lowest compared to their satisfaction with other variables examined throughout this study. Relevant recommendations for higher education institution are provided in the conclusion.

Keywords: Quality; Higher Education Institution (HEI); Quality Management; Quality Management System (QMS); Indicators.

\section{Introduction}

In today's competitive academic environment where students have wide range of alternatives when it comes to selection of higher education institution, it is very important to hear their opinions about quality, and use it to make appropriate improvements. This kind of feedback can be crucial in development and growth of institution.

This research is important mainly because of its contribution to both science and practice. The need for this research is twofold, practical and theoretical. In practical terms, there is no enough of literature written about this issue in this region so this will serve as a literature to fill the gap. Practical contribution refers to provision of important set of data for Star University which may result in adequate preventive and corrective measures.

The primary objective of this study is to examine students' perceptions towards different aspects of quality at HEI Star. The secondary objective is to compare results internally among nine 
variables and not only identify certain strengths and weaknesses of institution, but also to propose relevant recommendations.

Nine different variables resulted in a survey comprised of 71 question. Target population were students at HEI Star University. Students from all departments and cycles of study participated equally when it comes to numbers of their responses. Response rate of $82 \%$ was sufficient enough to make valuable conclusions.

As stated before this study is aimed to contribute to the quality improvement of HEI Star institution to analyze quality from different aspects, identify eventual problems and determine the critical points. In the same time, institution will have insight into its good aspects of quality, more accurately said, it will not only learn about its areas for improvement, but also about its strengths.

\section{Theoretical Background \& Literature Review}

Satisfaction is usually defined as the fulfillment or gratification of a desire, need or appetite. It is a function of relative level of expectations and perceives performance. Considering students as a consumers, who invest their time and money in higher education, universities should hear their voices and opinions toward the quality of services within an institution (Oliver, 2010).

There are many definitions of quality today, mainly due to many different meanings of this term in different contexts. In everyday life this term is used to explain different situations. Karim defined quality as anything that accords with the characteristics of the product to meet the external clients' needs (Newrian \& Cowling, 1996).

The ISO 9000 definition says that quality management is set of coordinated activities to direct and control an organization with regard to quality (ISO, 2001). On the other hand, Mekić and Goksu (2014) reported that Hoyle (2007) in his book identified several activities of quality management such are quality planning, quality control, quality improvement and quality assurance.

According to (Csizmadia, 2006), the term quality management refers to the policies, systems and processes which are designed to ensure the maintenance and enhancement of quality within an institution. Quality management, in the higher education context covers quality control, quality assurance and quality improvement. He also stated that quality management has made issues about academic standards explicit.

Currently, ISO 9001:2008 is well known and recognized as an international standard on best practices in internal quality management. This standard provides series of general requirements that can be applied regardless of the organization's size, activity or ownership (Laszibat, Sutic, \& Jurcevic, 2009).

In year 2005, European Network for Quality Assurance in Higher Education (ENQA) made first step in establishment of widely shared values, expectations, good practices related to quality and its assurance by institutions and agencies across the European Higher Education Area (EHEA). Standards and guidelines are prescribed in a manner that achievement of those is equal to implementing Bologna process. In other words, if these standards can be achieved, Bologna process can be achieved as well. Main aim of ESG is to support and encourage development of HEIs, which will foster educational achievements (ESG, 2005). ENQA developed standards and guidelines regarding internal and external quality assurance for the use of HE institutions and quality assurance agencies working in the EHEA, covering key areas relating to quality and standards (ESG, 2005).

Variety of numerous sources including books, academic journal articles, conference proceedings and reports, standards and guidelines for quality management, together with official websites, were carefully reviewed and considered while working on this study. See the Figure 1. Quality was always important for people, and even in 1986, it was in focus of researchers. Juran (1986) presented three elements of quality trilogy: quality planning, quality control, quality improvement.

The quality study was also focus of White (1999) whose main focus of study was Capital College of Pennsylvania State University and he provides some framework toward accreditation which is closely related with a quality. Book of Klarić (2005) was important source for literature of this work since it goes briefly through quality definitions, quality systems, quality management, preparation of organization for quality, quality documents system, measurement, examination, control, costs of quality, information system, audits, certification of quality system, accreditation 
and systems for it. The work of Holjevac (2005) was very helpful as well. Very useful for understanding quality issues in context of Higher Education was book of Tibor Gabor Csizmadia (2006) which introduces governmental reform and quality in higher education in Hungary. Basic purpose of the book was to answer question how

Bologna Declaration (1999) was used to explain basic principles of this influential document. One of these principles is related to quality of HEIs, which is another factor that increases importance of quality for HEIs located in B\&H, a state that signed Bologna Declaration in 2003. Klarić, Bajramović, Islamović, \& Hodžić (2011) provided important information about accreditation as a national methodology to assure quality of HEIs and implement Bologna process in the state level.

Kemenade \& Hardjono (2009) wrote a paper with purpose to define what factors cause willingness and resistance among lecturers towards external evaluation systems with special focus to accreditation. Very important conclusion of this work suggests that if we define accreditation after ISO 17011:2004 as: "third-party attestation related to a conformity assessment body conveying formal demonstration of its competence to carry out specific conformity assessment tasks," accreditation in higher education is more comparable to what ISO calls certification.

\section{Data}

The data has been collected using survey comprised of 71 question. Demographics part was in the beginning of the survey and followed by other questions grouped according to following variables: quality in general, quality of academic stuff, quality of administrative staff, campus, services, study programs, personal development, education facilities, cafeteria.

Target population were students at HEI Star University. Students from all departments and all three cycles of study including undergraduate, master and doctorate level participated equally. Response rate of $82 \%$ was enough to generalize data and provide valuable conclusions. The university where this research have been done is reputable private university in Bosnia and Herzegovina. The institution is following and implementing ISO 9001:2008 as well as European Standards and Guidelines (ESG).

\section{Methodology}

The aim of this research was to examine the perceptions of students towards quality of services at private higher education institution in B\&H. The survey was the main instrument of data collection and it has been divided into ten major sections. The first section contains questions about personal profiles of the respondents including gender, department of studying, fees, current level of study, country from were a student is coming. The second section contains questions about quality in general and the third section is based on questions about quality of academic staff. The fourth section contains questions about quality of administrative staff, while questions in fifth section are based on campus of university. In sixth section, questions are regarded to services at university and in seventh section they are about study programs that are offered at university. The eight section contains question about personal development and the ninth section is based on questions about education facilities. The tenth section contains questions regarding to cafeteria at university.

More accurately said, the instrument to collect data has been based on nine variables, and all of them are mentioned as important aspects of quality in higher education in ESG (2005) standards as well as HEA (2010) standards.

The measurement instrument used is a seven-point Likert scales is representing a range of attitudes from 1 - strongly disagree to 7 - strongly agree used to measure service quality, representing a range of attitudes from extremely dissatisfied (1) and extremely satisfied (7) to measure students' satisfaction. The meaning of following numbers is as follows: 1 - Extremely dissatisfied; 2 - Dissatisfied; 3 - Slightly dissatisfied; 4 - Slightly Satisfied; 5 - Satisfied; 6 Extremely satisfied.

\section{Results}

Nine variables have been used to provide information about perceptions of students towards quality of services at HEI Star University. A summary of responses to each of the nine variables is 
presented in following sections of this study. In the first part, under section demographics, important information about respondents will be explained. After that, the second part will present and explain results regarding each individual variable. The third part will present some suggestions for improvement when it comes to quality at Star University.

\section{Properties - Demographics}

In this part of survey, interviewees were asked about their faculty, department, cycle of study, what is their highest qualification planned for future, what are their yearly fees for education in BAM, what are their age group, gender, countries and do they use any scholarship. Fifty two respondents were from Faculty of Education, 198 of respondents were from Faculty of Engineering, 152 of respondents were from Faculty of Economics and 46 from Preparatory School of English language.

\section{Survey results}

According to respondents' answers following table is prepared with questions and with counted averages for every question and for every variable.

Table 1: Quality in general

\begin{tabular}{|l|c|}
\hline Variable: Quality in general & Mean \\
\hline Questions & 5,05 \\
\hline How do you rate the quality of the institution's services in general? & 4,84 \\
\hline How do you describe your feelings toward the institution's services in general? & 4,94 \\
\hline How likely are you to recommend the institution & 5,35 \\
\hline
\end{tabular}

The purpose of this variable was to evaluate students' satisfaction of quality in general. The mean value of 5,05 indicated that students agreed with offered statements, and that they are satisfied with the general quality of Star university.

The lowest value is related to question "How do you rate the quality of the institution's services in general?" with 4,84. Still, this is in region of slight agreement with the statement which indicates slight satisfaction of students. Important to emphasize is mean value of 5,35 by which respondents agreed that they would recommend Star university.

Table 2: Quality of academic staff

\begin{tabular}{|l|c|}
\hline Variable: Quality of academic staff & Mean \\
\hline Questions & 5,34 \\
\hline Academic staff have the knowledge to answer my question relating to the course & 5,39 \\
\hline Academic staff deal with me in a caring and courteous manner & 5,36 \\
\hline Academic staff are never too busy to respond to my request for assistance & 5,24 \\
\hline When I have a problem academic staff show a sincere interest in solving it & 5,39 \\
\hline Academic staff show positive attitude towards students & 5,50 \\
\hline Academic staff communicate well in the classroom & 5,41 \\
\hline Academic staff allocate sufficient and convenient time for consultation & 5,27 \\
\hline Academic staff provide feedback about my progress & 5,18 \\
\hline Academic staff are highly educated and experienced in their respective field & 5,31 \\
\hline
\end{tabular}

The purpose of this variable was to evaluate students' satisfaction towards quality of academic staff. The mean value of 5,34 indicated that that students at Star University are satisfied 
with quality of academic staff in this institution. The lowest mean value of 5,18 is linked with the providing feedback about students' progress, still this value is in positive interval of the scale indicating that students are satisfied with this aspect. The highest grade of students, mean value of 5,50 indicated high satisfaction level of students with practice that "Academic staff show positive attitude towards students".

Table 3: Quality of administrative staff

\begin{tabular}{|l|c|}
\hline Variable: Quality of administrative staff & Mean \\
\hline Questions & 5,14 \\
\hline When I have a problem, administrative staff show sincere interest in solving it & 5,18 \\
\hline $\begin{array}{l}\text { Administrative staff provide caring and individual attention. } \\
\text { Administrative staff are never too busy to respond to a request for assistance }\end{array}$ & 5,13 \\
\hline Administrative offices keep accurate and retrievable records & 5,02 \\
\hline When the staff promise to do something by a certain time, they do so & 5,10 \\
\hline The opening hours of administrative offices are personally convenient for me & 4,99 \\
\hline Administrative staff show positive work attitude towards the students & 5,09 \\
\hline Administrative staff communicate well with students & 5,26 \\
\hline Administrative staff have good knowledge of the system/procedures & 5,21 \\
\hline Students are treated equally and with respect by staff & 5,28 \\
\hline The staff respect my confidentiality when I disclosed information to them. & 5,02 \\
\hline
\end{tabular}

The mean value of respondents when it comes to quality of administrative staff was 5,14. It is possible to conclude that students at Star University are satisfied with quality of administrative staff in this institution. The lowest mean value of 4,99 is linked with the question „The opening hours of administrative offices are personally convenient for me“, but still it belongs to region of slight satisfaction. Equal and respectful treatment of students has been graded with highest value of 5,28 which means that students are highly satisfied with this aspect.

Table 4: Quality of campus

\begin{tabular}{|l|c|}
\hline Variable: Quality of campus & Mean \\
\hline Questions & 4,35 \\
\hline The institution has a professional appearance/image & 5,02 \\
\hline The institution has and ideal location with excellent campus layout and image & 4,24 \\
\hline The university has an easily accessible location & 4,06 \\
\hline The parking services at the university are adequate & 3,55 \\
\hline The university campus has a safe environment & 4,90 \\
\hline
\end{tabular}

The average of respondents' answers about quality of campus was 4,35 that means that students are slightly satisfied speaking about this variable. The lowest mean value of 3,55 occurred in a case of fourth question that is about parking services at Star University and conclusion can be that students are slightly dissatisfied with current situation of parking services at Star University. The highest value of 5,02 in this variable students gave to the institution's professional apperiance.

Table 5: Quality of services

\begin{tabular}{|l|c|}
\hline Variable: Quality of services & Mean \\
\hline Questions & 4,94 \\
\hline Inquires/complaints are dealt with efficiently and promptly & 4,69 \\
\hline I feel secure and confident in my dealings with the institution & 5,12 \\
\hline The institution provides services within reasonable/expected time frame & 5,11 \\
\hline Students are given fair amount of freedom & 5,01 \\
\hline
\end{tabular}




\begin{tabular}{|l|l|}
\hline The institution operates excellent counselling services & 5,00 \\
\hline Health services are adequate & 4,68 \\
\hline Information services via web-site is adequate & 4,94 \\
\hline The institution values feedback from students to improve service performance & 5,09 \\
\hline The university provides services for studentswith special needs & 4,83 \\
\hline
\end{tabular}

Average of answers regarding to quality of services is 4,94 which means that students are slightly satisfied with services that Star University provided to them. The lowest average $(4,68)$ was at sixth question in this variable that is about adequate health services. Still, it is important to state that this mean value reflects slight satisfaction of students with this aspect of service. The highest mean value of 5,12 regarding this variable occurred when it comes to question „I feel secure and confident in my dealings with the institution".

Table 6: Study programs

\begin{tabular}{|l|c|}
\hline Variable: Study programs & Mean \\
\hline Questions & 5,08 \\
\hline The institution runs excellent quality programs & 5,01 \\
\hline The institution offers a wide range of programs with various specialization & 5,12 \\
\hline The institution offers programs with flexible syllabus and programs & 5,02 \\
\hline The institution offers highly reputable programs & 5,28 \\
\hline The institution's graduates are easily employable & 4,98 \\
\hline
\end{tabular}

The mean value regarding this variable which is 5,08 means that students are satisfied with study programs at Star University. The lowest value of 4,98 belongs to fifth question which is about ease of getting the employment after graduation. Still, it is important to state that this mean value is confidentially positive meaning that students are satisfied with the ease of employment once they graduate. The highest mean value of 5,12 in this variable is in the question „The institution offers a wide range of programs with various specialization".

Table 7: Personal development

\begin{tabular}{|l|c|}
\hline Variable: Personal development & Mean \\
\hline Questions & 4,67 \\
\hline Recreation and sport facilities at university are adequate & 4,27 \\
\hline $\begin{array}{l}\text { Extracurricular activities (seminars, workshops, etc.) at university are adequate (music, } \\
\text { painting, photography, etc.) }\end{array}$ & 4,74 \\
\hline $\begin{array}{l}\text { Services and facilities of art at the university are adequate (music, painting, } \\
\text { photography, etc) }\end{array}$ & 4,52 \\
\hline The university support students' personal development projects & 4,87 \\
\hline $\begin{array}{l}\text { International cooperation programs at the university (student exchange, study visits, } \\
\text { etc) are adequate }\end{array}$ & 4,95 \\
\hline
\end{tabular}

From Table 7, it is possible to conclude that interviewees are slightly satisfied about opportunities of personal development at Star University. This is indicated by mean value of 4,67. The lowest mean value $(4,27)$ occurred in a case of question about recreation and sport facilities at Star University, while the highest mean value (4.95) belong to the question about adequate International cooperation programs at the university (student exchange, study visits, etc).

Table 8: Education facilities

\begin{tabular}{|l|c|}
\hline Variable: Education facilities & Mean \\
\hline Questions & 5,12 \\
\hline Academic facilities are adequate for quality education & 5,09 \\
\hline
\end{tabular}




\begin{tabular}{|l|c|}
\hline Class sizes are adequate for quality education & 5,00 \\
\hline The library services at the university are adequate & 5,29 \\
\hline The institution has up to date equipment & 5,11 \\
\hline The labs at the university are adequate for quality education & 5,21 \\
\hline The university provides up-to-date information technology for students. & 5,09 \\
\hline
\end{tabular}

From Table 8, the one may conclude that students are satisfied with educational facilities at Star University. This is obvious when considering mean value of 5,12 . The lowest students' satisfaction is presented in questions about sizes of classes with 5,00. It is important to say that this does not mean that students are not satisfied since the mean value of 5,00 belongs to positive part of the scale indicating that students are satisfied with the sizes of classes. The highest value $(5,29)$ belong to question about library services at Star University meaning that satisfaction level with library services is very high.

Table 9: Cafeteria

\begin{tabular}{|l|l|}
\hline Variable: Cafeteria & Mean \\
\hline Questions & 4,23 \\
\hline The university cafeteria provides high quality food and beverages & 3,88 \\
\hline Prices at the university cafeteria are reasonable & 3,80 \\
\hline The food variety is adequate & 3,91 \\
\hline The university cafeteria is clean & 4,78 \\
\hline Cafeteria staff provide good quality service to students & 4,76 \\
\hline
\end{tabular}

From table 9, the one can conclude that students are slightly satisfied with cafeteria at Star University This is indicated by mean value of 4,23 . The lowest students' satisfaction is presented in question about prices in cafeteria at Star University 3,80 while the highest value is related to the question "The universty cafeteria is clean" $(4,78)$.

Figure 1 offers comparative analysis indicating that "Quality of Academic Staff" is variable with the highest quality level in eyes of students. This might mean that Star University should continue with its positive practices when it comes to sourcing and improvement of academic staff. On the other hand, Figure 1 indicated also that Star University might consider undertaking some activities to improve quality of campus, especially when it comes to parking area for students.

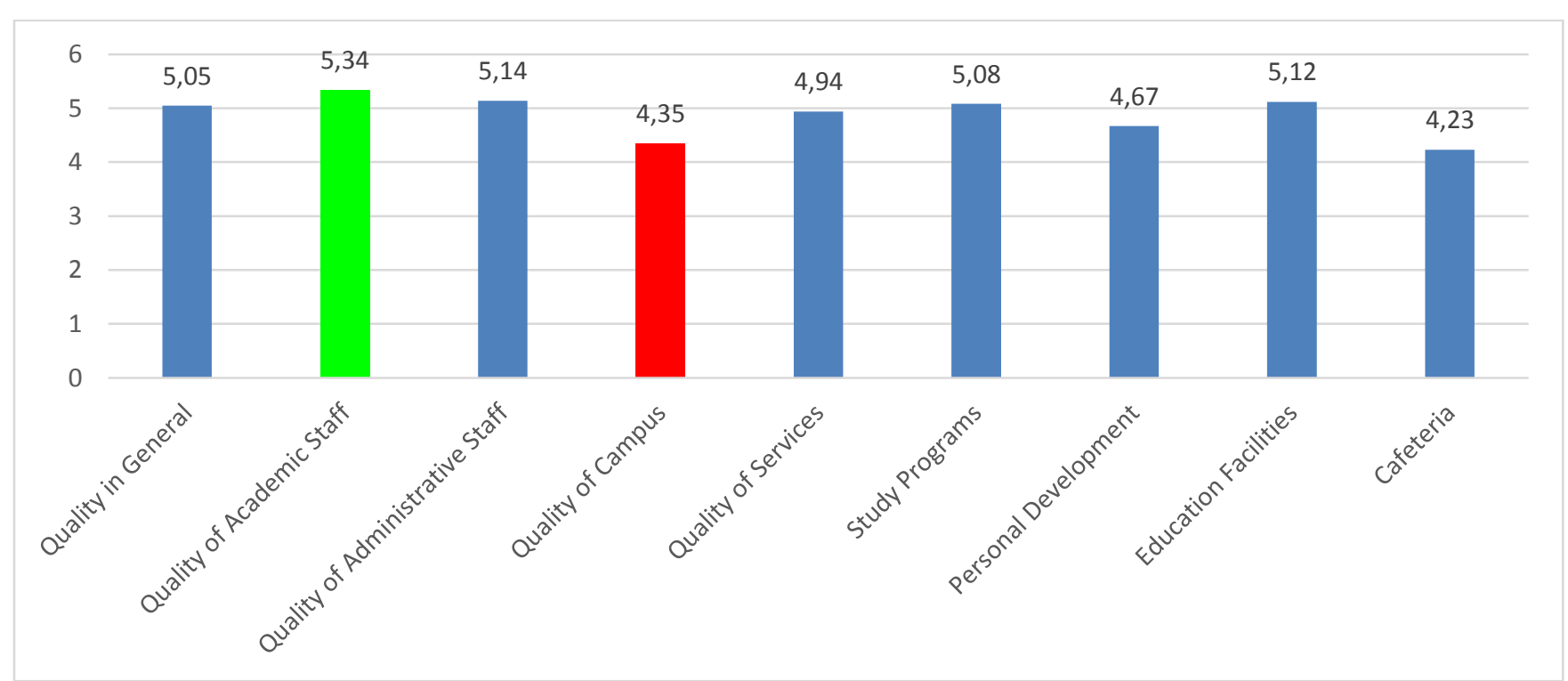

Figure 1: Comparative Analysis of Students Satisfaction with Different Aspects of Quality at Star University

\section{Conclusion}


The main objective of this exploratory study was to provide insights into perceptions of students towards quality of services at private higher education institution Star, located in B\&H, to identify its strong and weak points, and to offer recommendations for improvement when it comes to weak points. A survey as a main instrument has been developed on the basis of ten variables which are ten different aspects of quality in higher education mentioned in ESG (2005) and HEA (2010) standards for quality assurance. Even 448 students participated in the study. Main methodology used for purpose of data analysis is descriptive statistics.

Findings indicated that students are "slightly satisfied" and "satisfied" with all aspects of quality at higher education Star. The highest satisfaction level appeared when it comes to "Quality of Academic Staff" which means that this is definitely one of important strengths of the institution. Accordingly, Star University should continue with its positive practices when it comes to sourcing and improvement of academic staff. Even though students are still satisfied with "Quality of Campus", the satisfaction level is lowest compared to their satisfaction with other variables examined throughout this study. Therefore, Star University might consider undertaking some activities to improve quality of campus, especially when it comes to parking area for students.

\section{References:}

1. Bologna Declaration. (1999). Bologna: European Ministers of Education.

2. Csizmadia, T. G. (2006). Quality Management in Hungarian Higher Education. The Netherlands: CHEPS/UT.

3. ESG. (2005). Standards and Guidelines for Quality Assurance in the European Higher Education Area. Helsinki, Finland.

4. HEA. (2010). Criteria for Accreditation of Higher Education Institutions in Bosnia and Herzegovina.

5. Holjevac, A. (2005). Europa znanja: Organizacija koja uči i sustav upravljanja kvalitetom (Europe of knowledge: learning organization and quality management system). Kvalitet (Quality), 15(3-4).

6. Hoyle, D. (2007). Quality Management Essentials.

7. ISO. (2001). BAS EN ISO 9000:2001. International Standardization Organization.

8. Juran, J. M. (1986). The Quality Trilogy. 4oth Annual Quality Congress. California.

9. Kemenade, E. V., \& Hardjono, T. W. (2009). Professionals freaking out: the case of accreditation in Dutch higher education. The TQM Journal, 25(5), 473-485.

10. Klarić, S. (2005). Upravljanje kvalitetom. Mostar: Univerzitet "Džemal Bijedić"; Mašinski fakultet Mostar.

11. Klarić, S., Bajramović, E., Islamović, F., \& Hodžić, A. (2011). Integrated System of Quality in Higher Education. Kvalitet 2011 (Quality 2011). Neum.

12. Lazibat, T., Sutic, I., \& Jurcevic, M. (2009). Quality Management System at The Faculty of Economics and Busienss. 31st Annual EAIR Forum : Vilnus, Lithuania.

13. Mekić, E., \& Goksu, A. (2014). Implementation of ISO 9001:2008 \& Standards for Accreditation at Private University in Bosnia and Herzegovina.

14. Newrian, K., \& Cowling, A. (1996). Service Quality Banki : The Experience of Tow British. 15. Oliver, R. (2010). Satisfaction: A Behavioral Perspective on the Consumer.

16. White, G. W. (1999). Building collections for accreditation: a case study. Collection Building, 18(2), 49-57. 